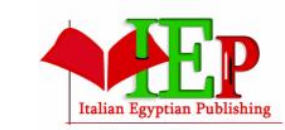

ISSN: 2785-9673

INTERNATIONAL JOURNAL OF

ARCHITECTURAL ENGINEERING AND URBAN

RESEARCH

VOLUME 3, ISSUE 2, 2020, 1-30.

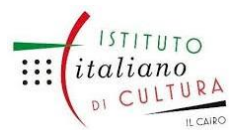

www.egyptfuture.org/ojs/

\title{
The Role of Contemporary Biographical Museums in Heritage Conservation in the UAE
}

\author{
Sadeka. Shakour a, * \\ a Associate Professor, Department of Architecture and Design, Abu Dhabi University, UAE, Abu Dhabi
}

\begin{abstract}
The first generation of Museums in the UAE was more oriented towards displaying Artifacts and ethnographic segments of history. On the other hand, the current trend is more toward the changes and associated collective memories of the community in a rapidly developing modern nation state. His Highness, Sheikh Zayed Bin Sultan was the founder of the state and had a powerful and influential vision and personality that not only influenced his society, but also passed through to the whole Gulf region. Having a biographical Museum for Sheikh Zayed is essential for documenting and preserving the details of his personality and presenting different aspects of his life in an innovative manner. Such museum will allow younger, technology-oriented generations to follow in the footsteps of Sheikh Zayed Bin Sultan to develop and progress their country. In addition, a biographical museum will provide a platform to reconnect with the past to conserve UAE heritage. Emerging contemporary museums in Al-Saadiyat Island exemplify the shift, from traditional forts that were restored into museums, to new forms of spaces. This new type offers technologies to support the exhibition of Artifacts and objects in context and scale based on international design guidelines. Therefore, the biographical museum that is proposed by this research is to be built in Al-Saadiyat Island. This Paper aims to highlight the importance of having a modern/contemporary biographical museum in the conservation of UAE heritage, and applies interior design theories within an academic context in order to connect between theory and practice. The research will show some of the design proposals for such a type of museums.
\end{abstract}

\begin{tabular}{ll}
\hline Keywords & \\
- & Heritage Conservation. \\
$-\quad$ & Contemporary Biographical. \\
$-\quad$ & Emerging Contemporary Museums. \\
$-\quad$ & Preservation. \\
\hline
\end{tabular}


The first generation of Museums in the UAE was more oriented towards displaying artifacts and ethnographic segments of history. On the other hand, the current trend is more toward the changes and associated collective memories of the community in a rapidly developing modern nation state. His Highness, Sheikh Zayed Bin Sultan was the founder of the state and had a powerful and influential vision and personality that not only influenced his society, but also passed through to the whole Gulf region. Having a biographical Museum for SheikhZayed is essential for documenting and preserving the details of his personality and presenting different aspects of his life in an innovative manner. Such museum will allow younger, technology-oriented generations to follow in the footsteps of Sheikh Zayed Bin Sultan to develop and progress their country. In addition, a biographical museum will providea platform to reconnect with the past to conserve UAE heritage. Emerging contemporary museums in Al-Saadiyat Island exemplify the shift, from traditional forts that were restored into museums, to new forms of spaces. This new type offers technologies to support the exhibition of 
artifacts and objects in context and scale based on international design guidelines. Therefore, the biographical museum that is proposed by this research is to be built in Al-Saadiyat Island. This Paper aims to highlight the importance of having a modern/contemporary biographical museum in the conservation of UAE heritage, and appliesinterior design theories within an academic context in order to connect between theory and practice. The research will show some of the design proposals for such a type of museums.

\section{Main Museums' Categories in UAE}

Museums are places which preserve historical artifacts and are considered as landmarks in their respective countries. There are different types of museums, Art museums, Cultural museums, Historical museums, scientific museums, Heritage museums \& Biographical museums. The presence of such diversity in the types of museums enhances the knowledgeof the foreigners about the culture of the UAE. It also contributes to shaping the mindset of the future generations of the Emirati youth, by demonstrating the cultural value of their country.

The first generation of Museums in the UAE aimed to preserve the national identity through recreating collective memory of the pre- 
petroleum community in the Gulf region. For example; Al Ain Palace Museum.

Al Ain Palace was built in 1937 for the UAE founder, late Sheikh Zayed Bin Sultan Al Nahyanand his family who lived in Al Ain until 1966. It was turned into a museum in 1998 and openedto the public in 2001. The structure of the palace consists of a combination of courtyards, thus merging the official and private use of the facilities in one complex. The aim of convertingthe palace into a museum was to allow the visitors to appreciate the life of the greatest fatherof the nation and his family during that period of time. Figure 1
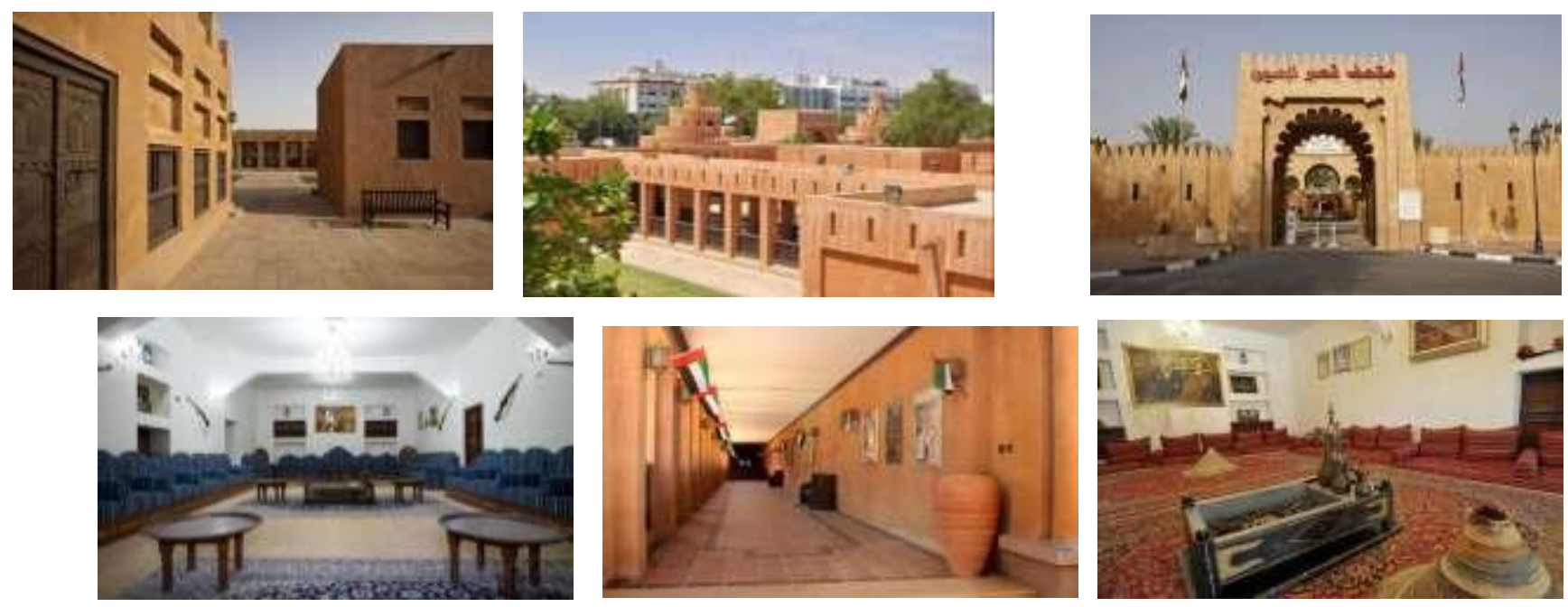

Figure 1; Display of Culture within traditional mediums in Al Ain Palace Museum 
This is in line with the traditional mission of museums, which is acquire, conserve art and artifacts, and apply research to historic documents and subsequently communicate these forms of collective memory to a wider audience for the purposes of study of the developmentof a society and its environment. (Morris, 2001)

As the types of museums vary, the purpose each museum serves vary accordingly. For instance, some museums favor conservation over reconstructing artifacts in context. While others allow the audience to experience and interact with the displayed items within an interactive context rather than a perseveration purpose.

However, active involvement between subject and object through different mediums can onlybe attained in new museum structures. This is because the building envelope of traditional heritage house cannot be modified to accommodate new technologies that rely on mechanical systems to display the social development of Emirati culture over time. Traditional museums help retain the development of a nation such as 
the UAE. However, it is essential to link the nation's past to its present and future and preserve its contemporary identity in an Arab world that is witnessing modernity in rapid and extensive mediums within a globalized world.

In our contemporary world, tools of presentation of history and heritage have changed, as arts of new media redefine the traditional roles of curators and shifted to new collaborative models of production and
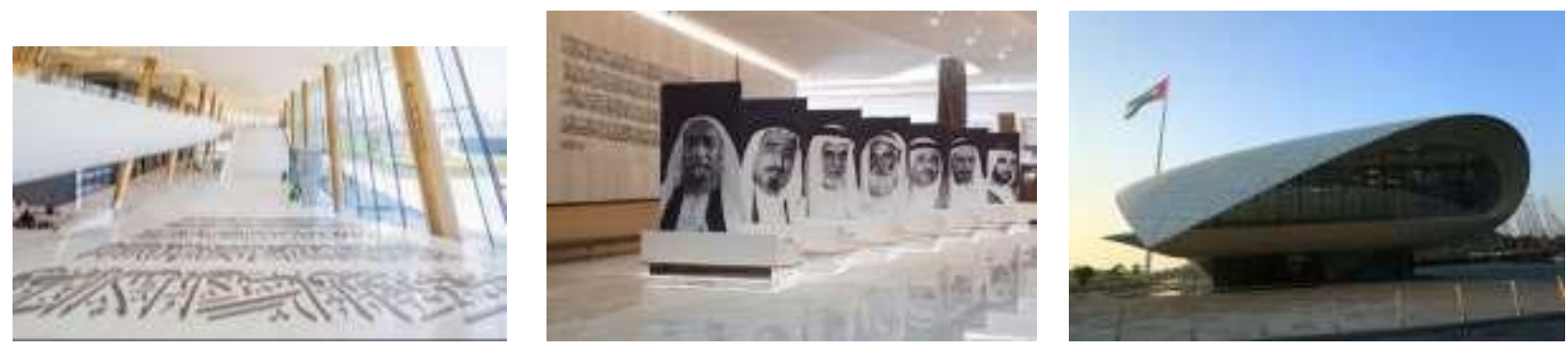
presentation. For example, the Etihad Museum offers a presentation of Emirati culture within modern interactive mediums that allow visitors to experience culture within a contemporary context. Figure2
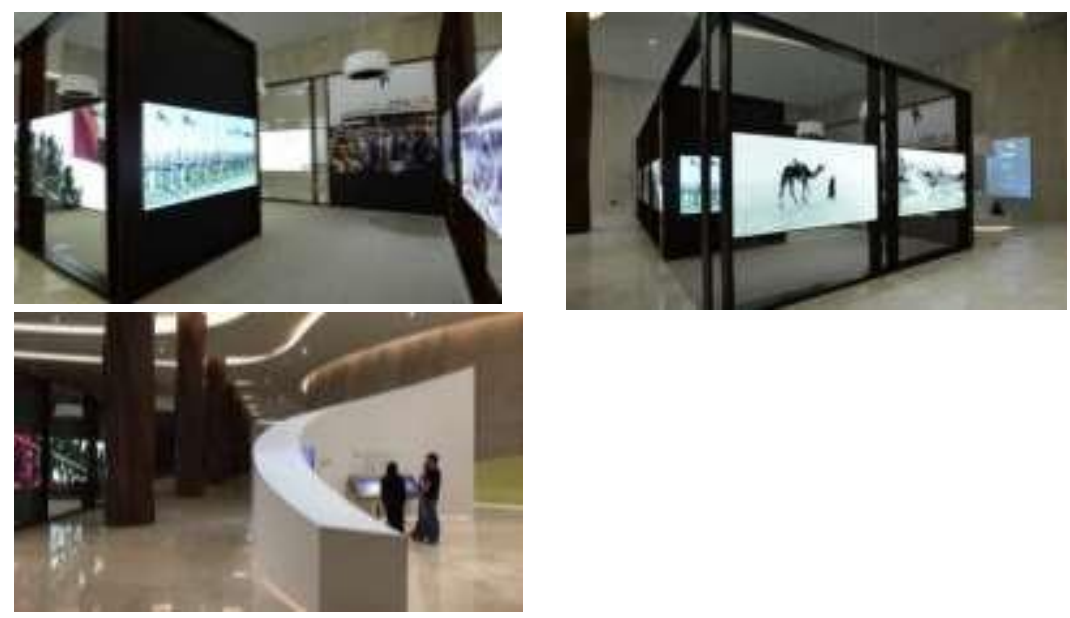

Figure 2. Display of Culture within contemporary mediums in Etihad museum

The museum tells the story of the foundation of the UAE. This is expressed through the entrance design, which consists of the shape of a manuscript with seven columns simulatingthe pen that was used to sign the UAE declaration. This museum is one of the most famous buildings in Dubai and a well-known landmark throughout the UAE. The aim of this museumis to educate visitors and offer them an exclusive experience that allows them to discover theunion that led to the birth of 
the UAE. Moreover, the museum explains to the visitors the vision, determination, and wisdom of the nation's founding father.

The UAE has an interest to preserve its heritage and protect it from dilution within a constant exchange between local and international global mediums. This narrative is presented in thedisplay of artifacts in traditional museums in the UAE, which provide an overview of the traditions and cultures within an architectural, urban context in addition to archaeology and ethnography. For example, "Qasr Al Muwaiji" Museum. The museum presents a long standingrelationship between the Palace of Al Muwaiji and Abu Dhabi's leaders. In 1946, His Highness Sheikh Zayed bin Sultan Al Nahyan, father of the nation, moved to the Palace of Al Muwaiji with his family. The museum lets the visitors know the history of this great building where HisHighness Sheikh Khalifa bin Zayed bin Sultan AI Nahyan was born, grew up, and lived with his family. Moreover, the museum tells the story of his leadership, life, and accomplishmentsunder the instructions and guidance of his father, late Sheikh Zayed bin Sultan Al Nahyan, and later as the President of the UAE. Qasr Al Muwaiji exhibition is housed in a modern glassbuilding within the courtyard of the palace. Using a new material in the entrance and corridor, such as glass, makes the building more suitable and modern during the present days. Extending the window glass from the 
floor to the ceiling provides enough light during daytime and creates an enjoyable view from inside out and vice versa during evening time. Figure3
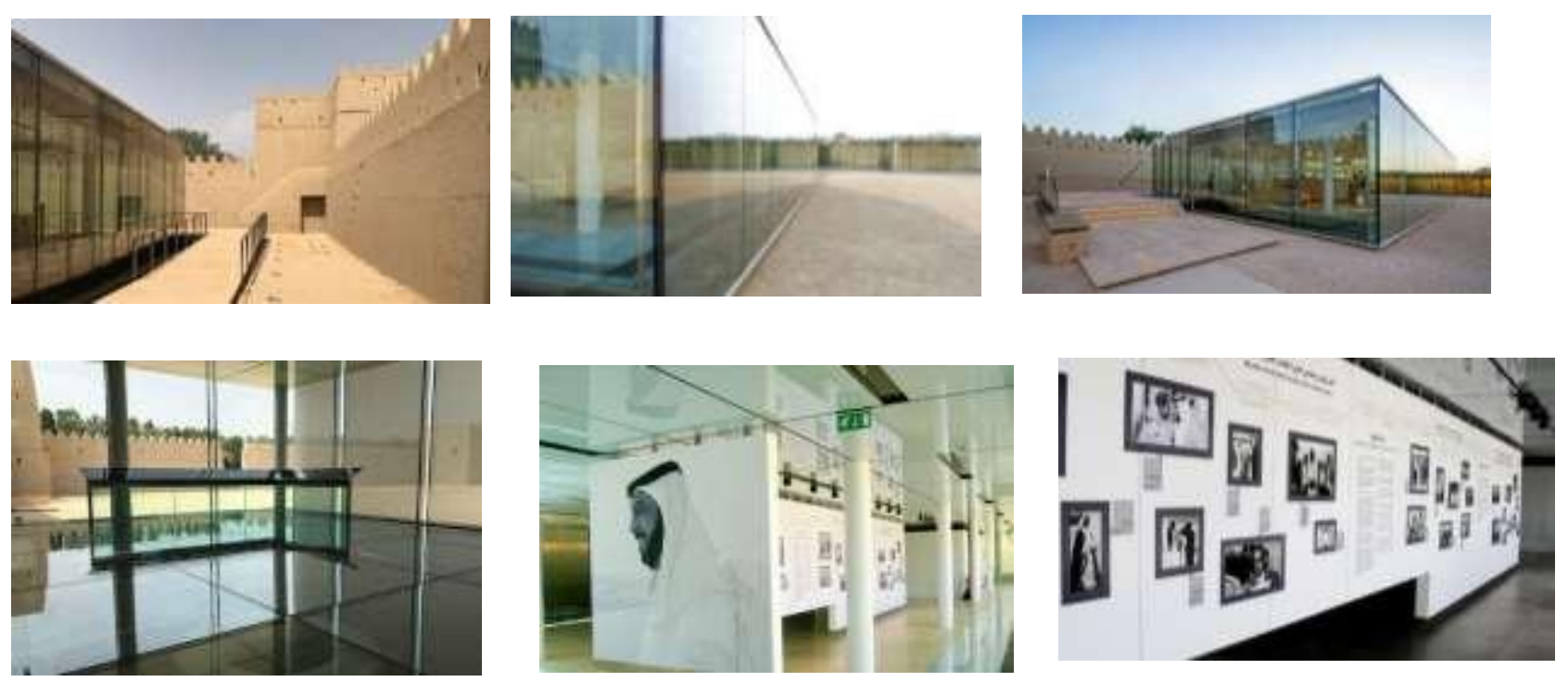

Figure 3. Display of Culture between the local and international global mediums in Qasr Al Muwaiji Museum 
Forthcoming museums such as the Zayed National Museum in Abu Dhabi are destinations that narrate the region's history, culture, and its development of a distinct persona. Al- Saadiyat Island's Cultural District is proving to be a strong beginning for the city to emerge as a cultural hub. For example, Manarat Al-Saadiyat, Abu Dhabi Louvre, Guggenheim Abu Dhabi and several performing arts centers are all new institutions that support the transformation of exhibition space from local to international. These museums as exemplifiedby Manarat Al-Saadiyat offer new spaces for experiencing history and intangible heritage through the use of alternative mediums to present art and culture in contemporary exhibitionspaces. Abu Dhabi Louvre is considered the first universal museum in the Middle East that translates the spirit of openness and dialogue of cultures. It displays works of historical, cultural, and sociological significance from past to present. Abu Dhabi Louvre was designedby Jean Nouvel and reaches 9,200 square meters of art galleries. The Louvre dome is a unique combination of traditional elements of Islamic and Arabic architecture and modern elements. The dome's geometric lace design, which has a fascinating 'rain of light' effect wasinspired by palm leaves that were used as a roofing material in UAE 
at the past. Its diameteris 180 meters and is supported by only four concrete piers. The holes in the museum's roof allow daylight to enter without excess solar gain. Figure 4

Today electronic and digital technologies continue to expand the possibilities of cultural dissemination. In Manarat Al-Saadiyat, contemporary art is juxtaposed to the developments of the city of Abu Dhabi throughout the years, presented within a context of site-specific installations. (Morris, 2001) Backdrop installations that provide the context of the exhibition are easily disassembled and reassembled once the timeframe of the temporary exhibition isfinished. However, such planning is technically more sophisticated than it seems, which highlights the importance of implementing a framework for interdisciplinary museum exhibition design. (Celik, 1992) For example, the internal open theatre in the center of exhibition spaces in Manarat alSaadiyat offers multiple modes of presentation of the future development of design in the city, as exhibited by the multiethnic persona of Abu Dhabi city and the contemporaneity of international designs such as the perforated dome of the Abu Dhabi Louvre .Such modern cultural media spaces inform visitors that they have interactive mediums to explore, inspire and create their own experience in the new generation of UAE museums. The new international museums in Al- 
Saadiyat explain the state interest in the movement towards public understanding of contemporary forms of art and exhibition spaces, and create new venues that aim to become centers of dialogue for citizens within acontemporary multi-ethnic society. (Soren, 2009)
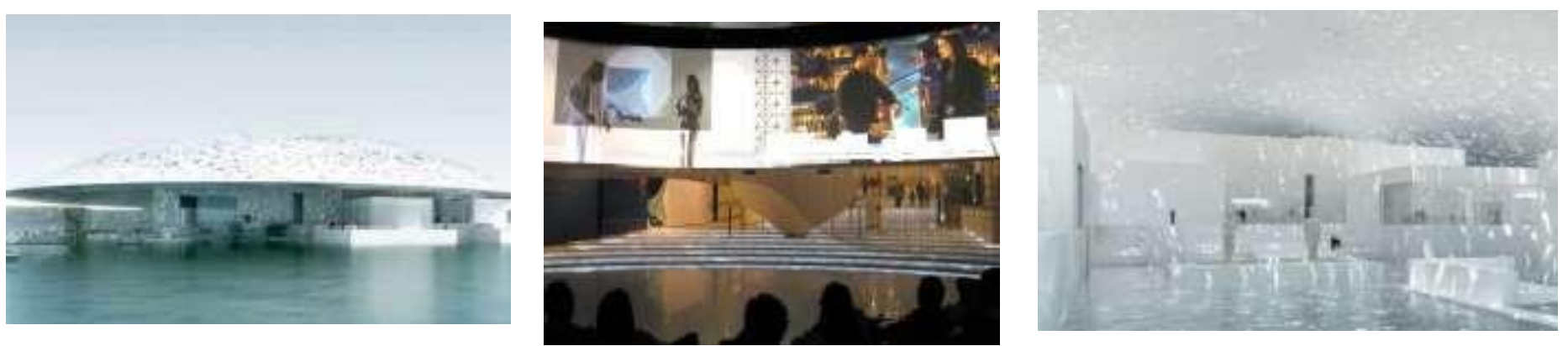

Figure 4. Digital mediums presenting the Abu Dhabi Louvre and further developments in Manarat Al-Saadiyat

\section{The Classification of biographical museums}

\section{Biographical Museum for an Artist}

Is a museum that displays all the artist works, books, collections, furniture, and tools. This type of museum makes the visitors indulge with all the details of the artist life and experienceto become their source of inspiration and creativity. This kind of art museum promotes and 
documents various professional schools in the mindset of visitors
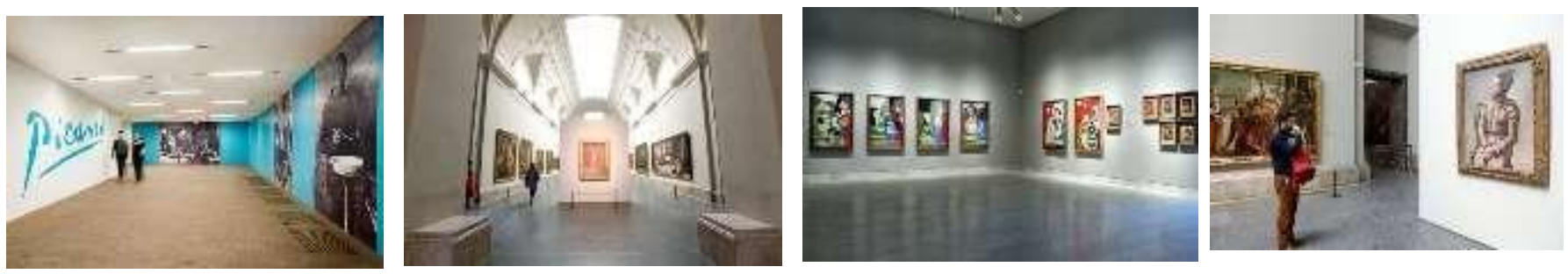

Figure 5. Pablo Picasso Museum in Madrid

\section{Biographical Museum for a Singer}

This is a museum that includes all the singer's belongings, rare records, letters, instruments, and awards. Umm Kulthum Museum is the first biographical museum in the Middle East andis located in Egypt. It was established by the Ministry of Culture in April 1998 to be located inthe heart of the Capital Cairo, honoring the memory of the Egyptian singer Umm Kulthum. Umm Kulthum mesmerized Arab audiences from the Persian Gulf to Morocco with her songs,for almost half a century. The 
Ministry of Culture collected all of her personal belongings (dresses, handbags, shoes, sunglasses, handkerchiefs, and accessories) , musical work (original manuscripts of her songs, and rare records), pictures, honors and awards that she received, and some letters from leaders and celebrities in order to display them all in the museum that attracted both Egyptians and foreigners.
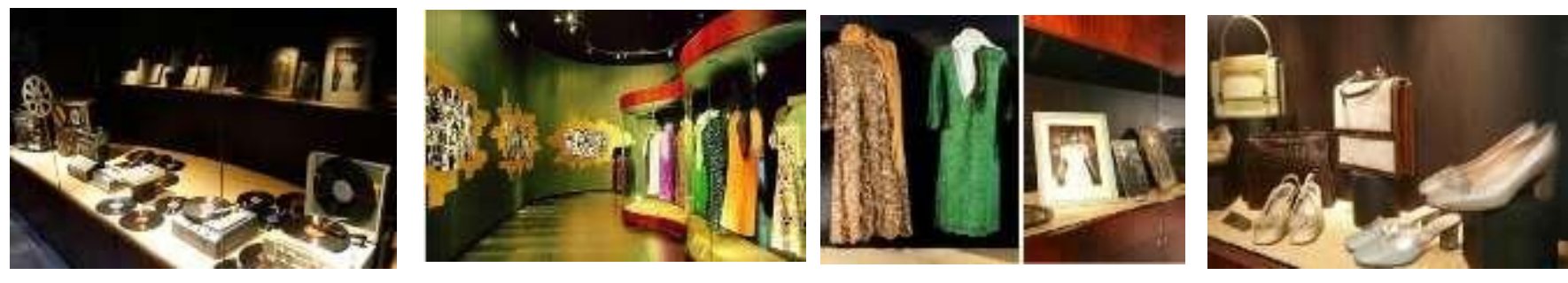

Figure 6. Umm Kulthum Museum in Cairo Egypt

Biographical Museum for Leaders

This type of museum tells the story of a leader's life details through pictures, paintings, belongings, and equipment that the leader figure used. This museum helps visitors to understand the depth of the difficulties that the leader is subjected to and the achievementsand successes that he has reached. 
reached.
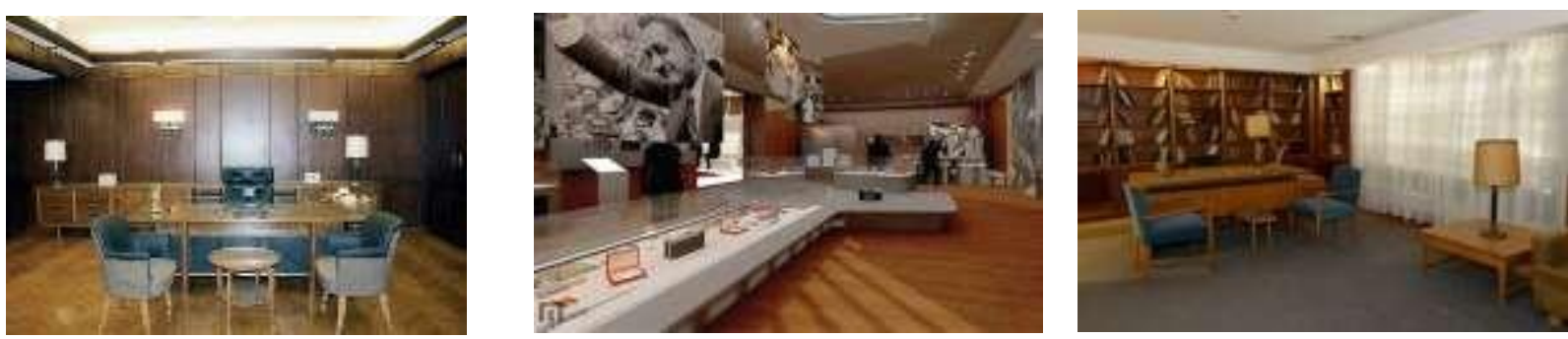

Figure 7. Jamal Abdul Nasser Museum,
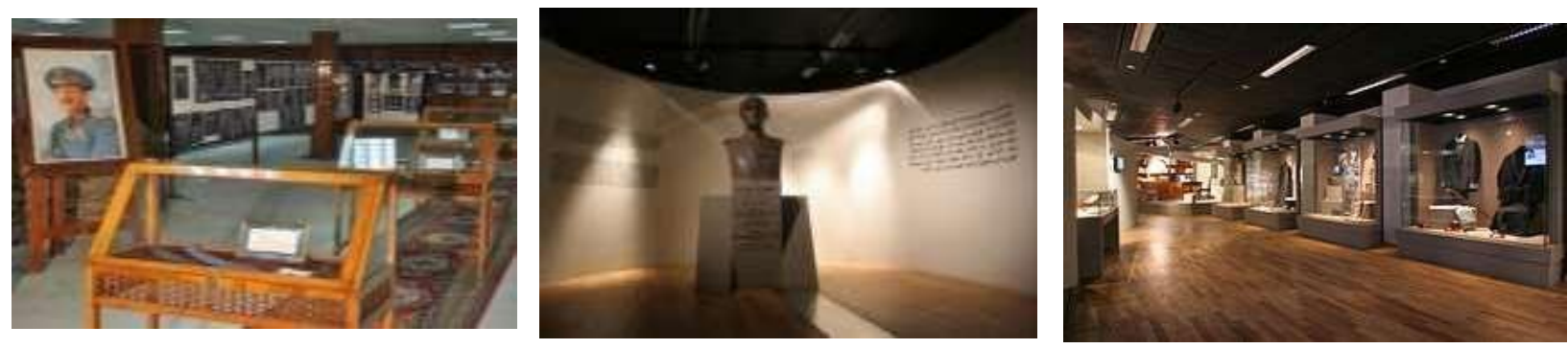

Figure 8. Anwar Sadat Museum, Egypt

Biographical Museum for a Royal Family

This is a museum that consists of all information and rare artifacts that are related to Royal Families along different periods of their rule. This museum includes Royal Family pictures, furniture, and sometimes
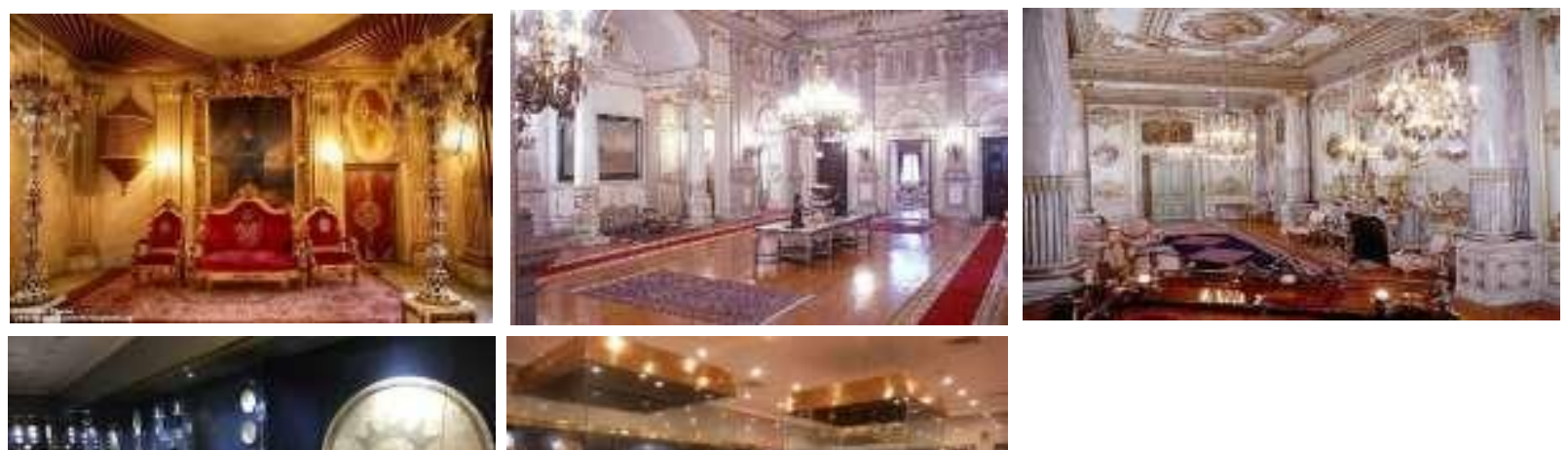
family trees of the age of decades. Furthermore, it shows how the king controls the country and manages its affairs

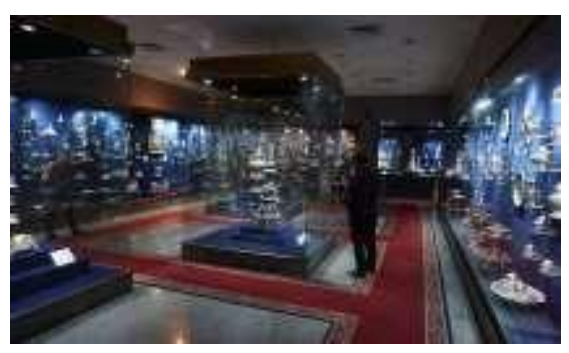

Figure 9. Abdeen Palace Museum - Cairo -Egypt

\section{Contemporary design of Sheikh Zayed Biographical Museum}

The purpose of designing a Sheikh Zayed museum is to provide a balance between the functional requirements, and aesthetic design. In this paper, the proposed design for a Biographical museum in Abu Dhabi aims to apply the interior design theories within an academic context, connecting both theory and practice. 


\section{About Abu Dhabi}

Abu Dhabi is the capital and largest city of the United Arab Emirates; its estimated area is $67,340 \mathrm{~km} 2$. It is a T-shaped island which is located in the heart of the Arabian Gulf in Asia. Abu Dhabi's population reached 2.784 million in 2017. During its development stage, Abu Dhabi's income depended solely on the trade of pearls. However, in 1958 the discovery of oilhelped the rapid growth and development of Abu Dhabi.

Abu Dhabi has a hot and humid desert climate, especially during the months of June to September, in which the average temperature rises above $38^{\circ} \mathrm{C}$. The cooler season starts from November to March, in which January is the coolest month of the year with an average temperature of $18.8^{\circ} \mathrm{C}$.

The population density of Abu Dhabi varies from area to area, as it is higher in the central downtown whereas it is lower in the suburban districts. Therefore, medium and high-rise buildings are built in the densest populated areas to accommodate the large group of people.Abu Dhabi is well known for many significant places, such as the Emirates Palace, Sheikh Zayed Mosque, and Yas Island. 

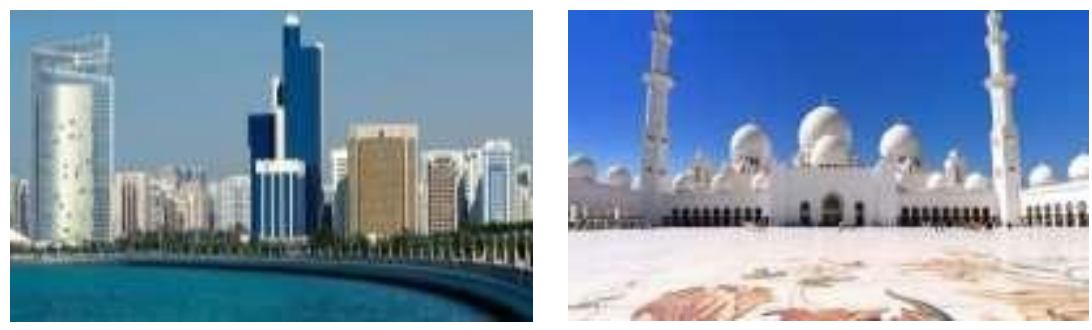

Figure 10. Abu Dhabi City

\section{Al Saadiyat Island}

Al Saadiyat is a large, 27000 square meters island, low-lying island, 500 meters (1,600 ft) offthe Coast of Abu Dhabi Island. Al Saadiyat is fiveminute drive far from downtown Abu Dhabi,20 minutes from Abu Dhabi International Airport and one hour from Dubai. It consists of commercial and residential areas that reflect the Emirati heritage and culture. It includes 145,000 residential houses, beach, restaurants...etc. Also, Al Saadiyat Island is mainly famous for being the cultural hub of museums and galleries in Abu Dhabi.

Due to its unique size and location, Al Saadiyat Island is chosen as a location to construct eight museums designed by internationally recognized architects such as Jean Nouvel, Tadao Ando, Frank Gehry 
and Zaha Hadid.

Al Saadiyat island is expected to witness further developments in 2020 , which will further enhance Al Saadiyat Island's location as a hotspot attracting all the regional and internationalvisitors for unique exhibitions, permanent collections, productions and performances.

Al Saadiyat island is considered the perfect location for the proposed museum design due tomany reasons. The services and offerings on the island makes it very convenient for all the visitors as it accommodates different needs, varying from hotels, restaurants, malls, supermarkets.

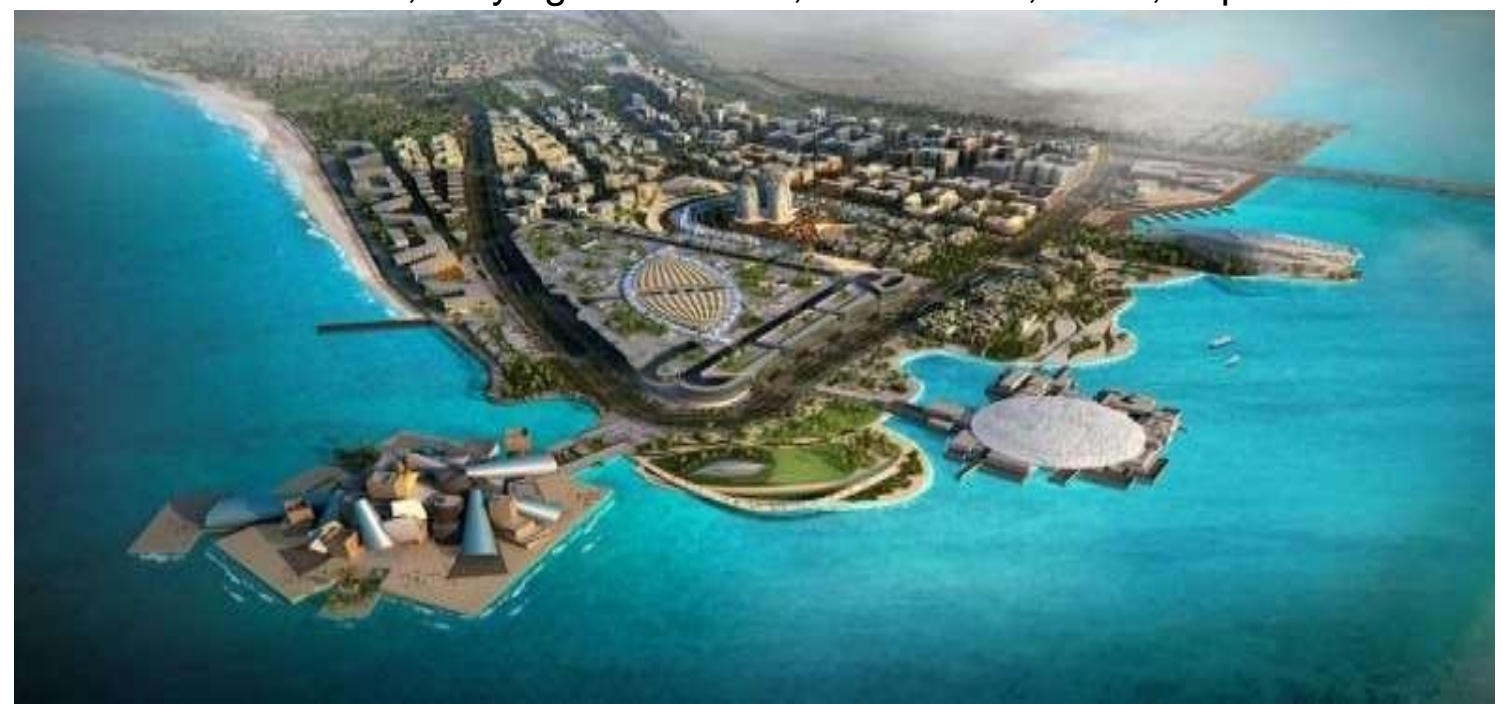


The construction of the museum in such a location will fulfill the needs of all the visitors. There are incidents where visitors do not visit a famous sightseeing attraction due to lack of parking spaces, services, other activities etc... Therefore, the construction of the museum on $\mathrm{AL}$ saadiyat Island will add credibility to the authenticity of the museum and will grant the visitors an experience that is both informative and fun.

Figure11. Al Saadiyat Island

As of now, the UAE has no dedicated place that offers all the information and collectibles of the greatfounder and Father of the UAE Sheikh Zayed bin Sultan Al Nahyan. This sheds light on the importance of the execution of this project as it will be the first museum established in the UAE solely dedicated to display the life of the Father of the UAE Sheikh Zayed bin Sultan AI Nayhan.

\section{Space Organization}




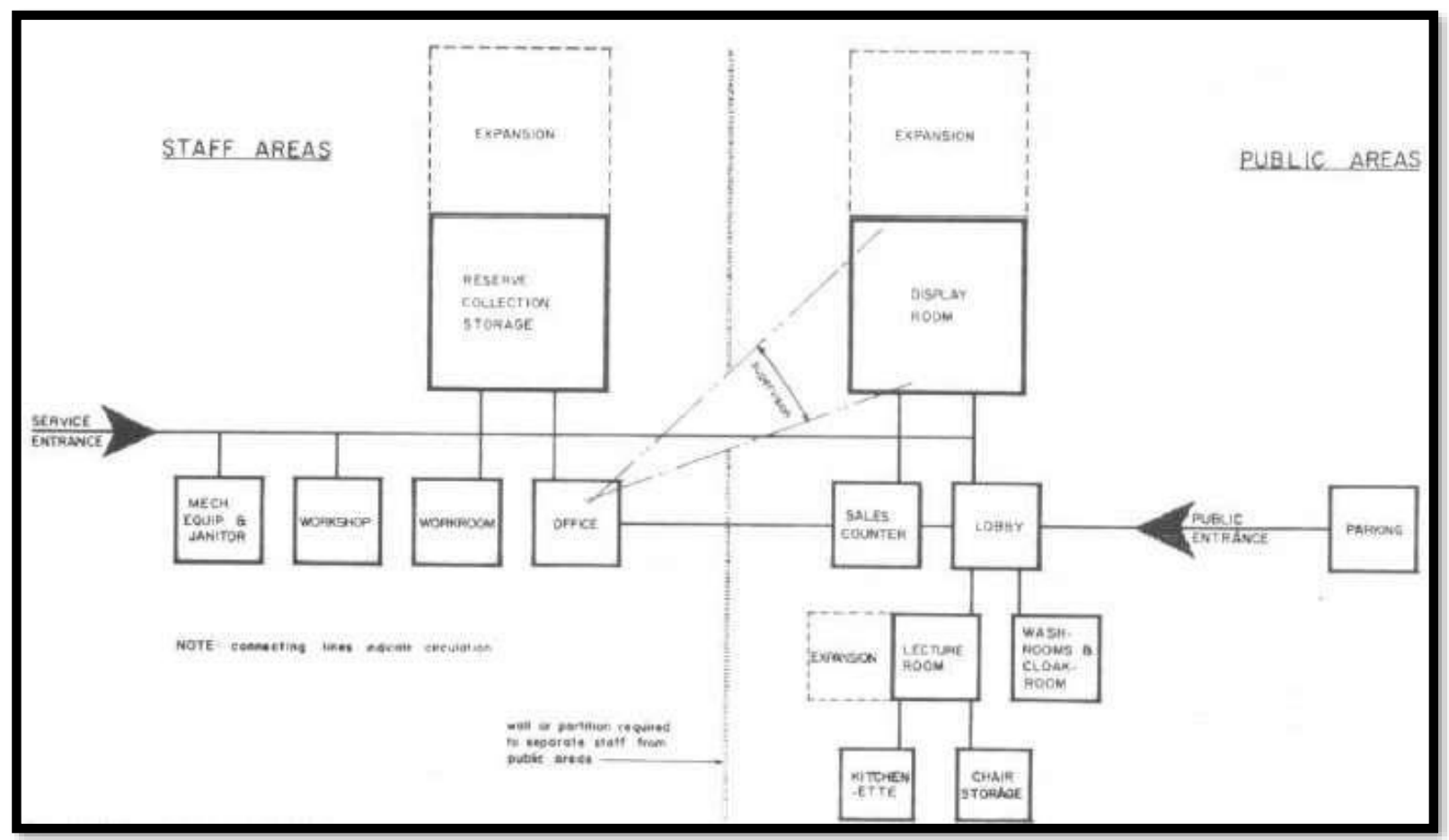

Figure12. Space organization diagram for small museums

\section{Proposed Space Organization}




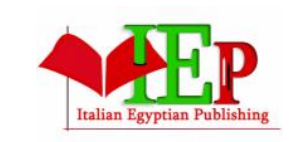

\section{INTERNATIONAL JOURNAL OF \\ ARCHITECTURAL ENGINEERING AND URBAN \\ RESEARCH}
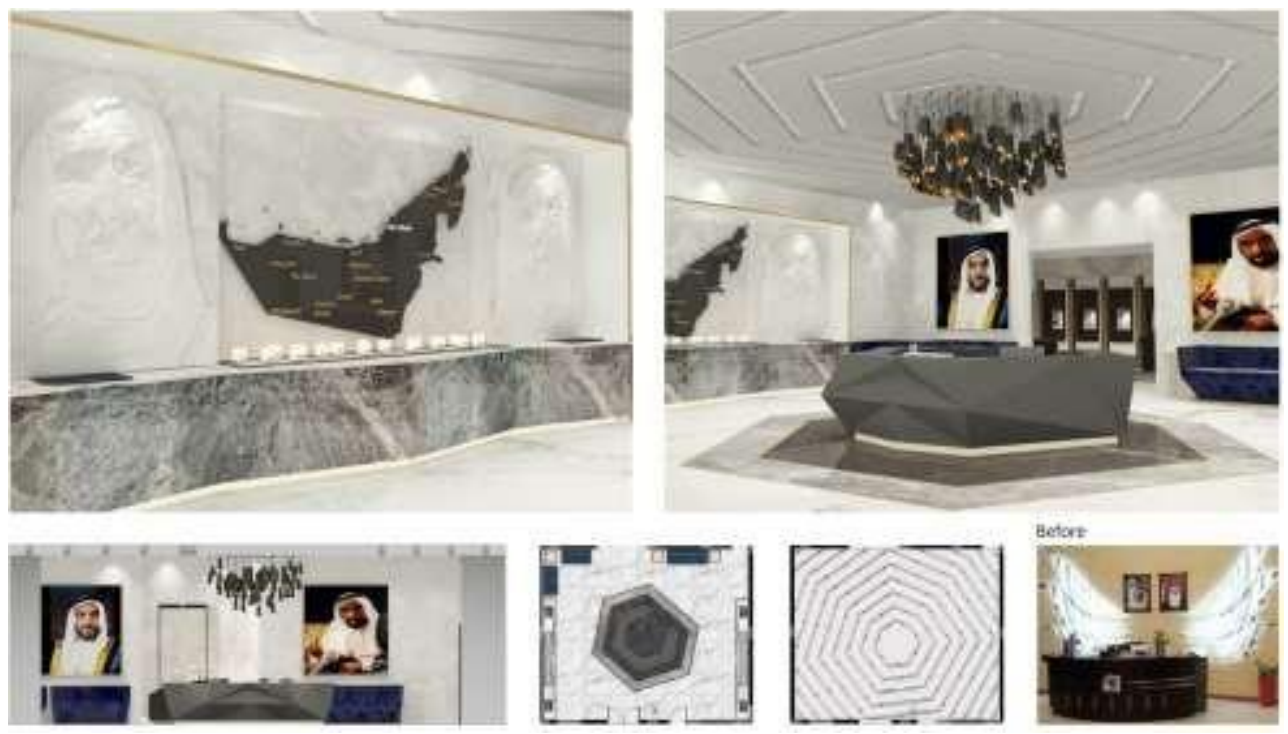

Figure 13. Examples of new form of reception within proposed museum spaces

\section{Reception:}

The reception (Figure 13) is the first area that the visitors interact with, and it provides them with all the information that they need. At the reception, the users can receive a general map that will guide them throughout the museum. Also, it provides them with brochures, catalogs, and postcards. 

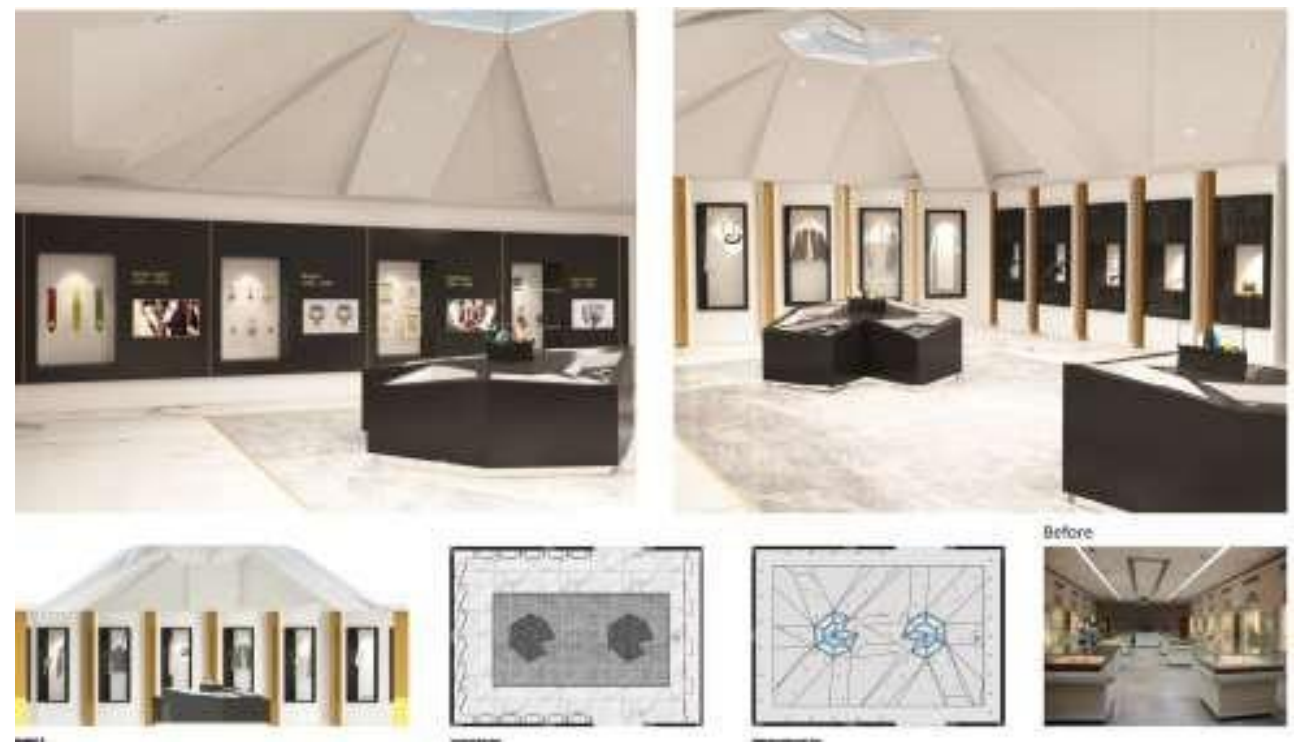

Figure 14. Examples of new form of Display Area for Collectibles within proposed museum spaces

\section{Display Area for Collectibles}

The Display Area for Collectibles (Figure 14) is the space in which the visitors observe all the collectibles of the Highest Father of the Nation late Sheikh Zayed bin Sultan Al Nahyan, allowing them to experience and appreciate the simplicity of the life style in the UAE duringthe leadership of H.H Sheikh Zayed bin Sultan Al Nahyan. 


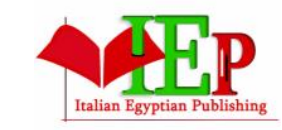

\section{INTERNATIONAL JOURNAL OF \\ ARCHITECTURAL ENGINEERING AND URBAN \\ RESEARCH}
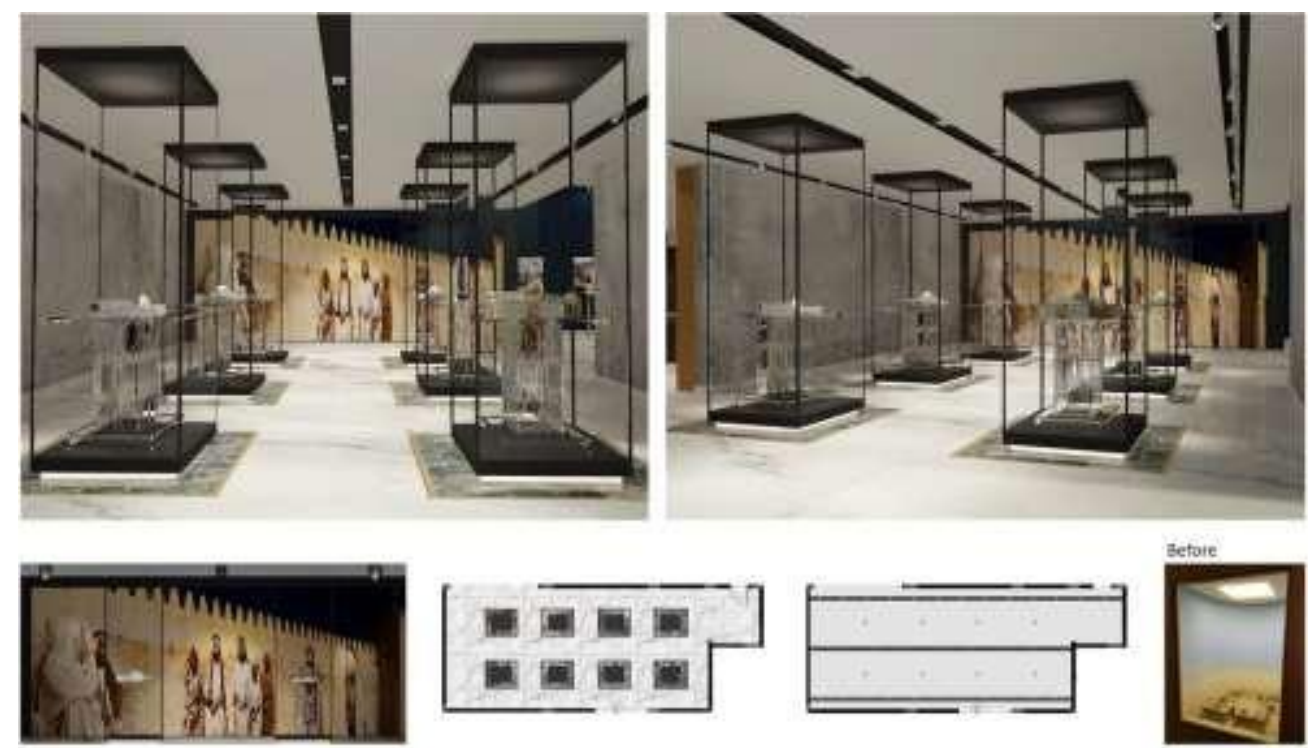

Figure 15. Examples of new form of Display Area for modeling within proposed museum spaces

\section{Display Area for Modeling}

The Display Area for Modeling (Figure 15) allows the visitors to get insights about the residential palace of the late Sheikh Zayed bin Sultan Al Nahyan and his family. 

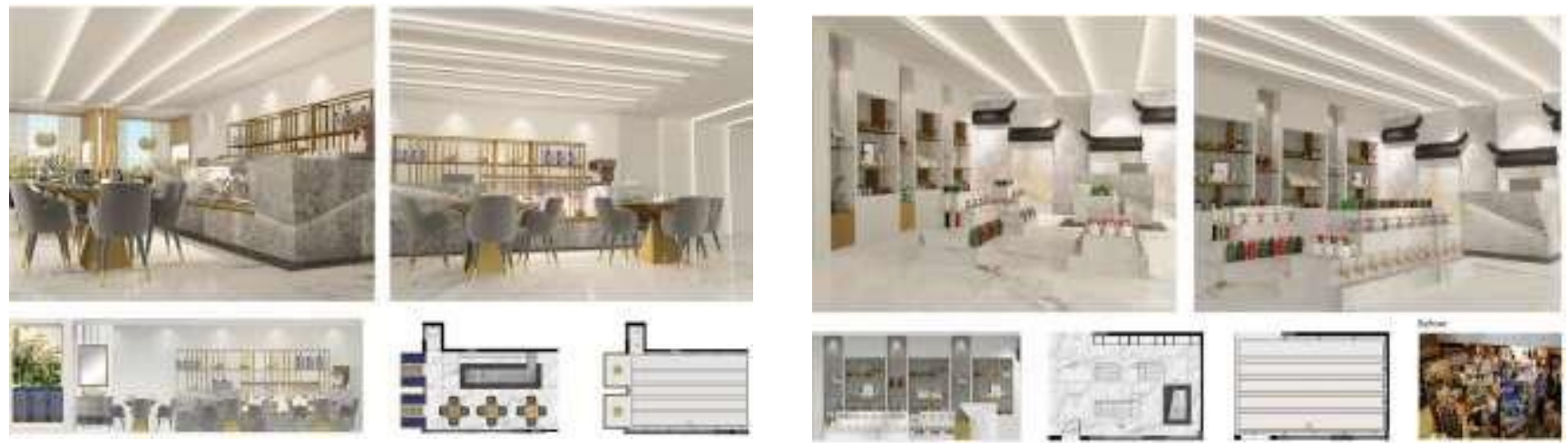

Figure 16. Examples of new form of cafe \& gift shop within proposed museum spaces

New Basic Functions

The proposed designs for the different basic functions mentioned earlier (Figure 16) also emphasize the importance of including facilities that are not easily integrated in the traditionalmuseums, such as a theatre and a Café to offer a resting and discussion place after the museum visit, where visitors can enjoy light meals after finishing the tour in the exhibitions.

\section{CONCLUSION}

- Considerations should be given to establish new types of museums, i.e. "Contemporary Future Museum" that rely on 
specific and advanced displays (e.g. biographical museums).

- Having a biographical Museum for Sheikh Zayed is essential for documenting and preserving the details of his personality and presenting different aspects of his life in an innovative manner. Such museum will allow younger, technology-oriented generations to follow in the footsteps of Sheikh Zayed Bin Sultan to develop and progress their country.

- a biographical museum will provide a platform to reconnect with the past to conserveUAE heritage

- Sole dependence on traditional museums, like historical or traditional fashion museums, is not enough in today's rapidly developing digital world.

- Contemporary Future museums should include an educational section or workshop in order to provide an attraction and opportunity for younger generations and visitors to learn their country's history and heritage.

- The "Contemporary Museum" project contains sections for innovation in museums in the UAE. In addition, they need to house a permanent museum of future inventions aswell as the best environment for creativity and innovation on a global scale.

- The museum aims to test the abilities of the human brain of 
developing long-term solutions to the future challenges that would face cities. It cares to create advanced high-tech museums combined with the vision of Abu Dhabi 2030.

\section{Bibliography}

1. A Planning Guide for Making Temporary Events Accessible to People. (2015). Retrieved fromAdata.

2. About UAE. (n.d.). Retrieved from Lonely Planet: https://www.lonelyplanet.com/united-arab-emirates/dubai

3. Abu Dhabi. (n.d.). Retrieved from Wikipedia: https://en.wikipedia.org/wiki/Abu_Dhabi

4. Al Ain National Museum. (2013). Retrieved from Abudhabi.ae.: https://www.abudhabi ae/

5. Al Ain Palace Museum. (n.d.). Retrieved from Visitabudhabi.ae: https://visitabudhabi.AlKhalij.(2010). History of Arts \& Media. http://www.uaepedia.ae

6. Anon. (2017). Retrieved from http://www.saadiyatculturaldistrict.ae/en/saadiyatcultural

7. Association, M. (March 2013). Public perceptions of and attitudes to The purposes of museums insociety. http://www. museumsassociation.org/download?id=954916.

8. Cairo.gov.eg. (n.d.). Retrieved from ttp://www.cairo.gov.eg/

9. Civilization, Museum of Islamic Civilization - Sharjah . (n.d.). Retrieved from My Art Guides:http://myartguides.com/art-spaces/non-profit/sharjah- 


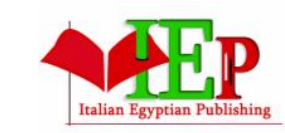

ISSN: 2785-9673

\section{INTERNATIONAL JOURNAL OF \\ ARCHITECTURAL ENGINEERING AND URBAN \\ RESEARCH}

VOLUME 3, ISSUE 2, 2020, $1-30$.

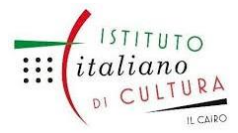

www.egyptfuture.org/ojs/

$\underline{\text { museum }}$

10. Department of culture and tourism Abu Dhabi. (n.d.). Retrieved from http://tcaabudhabi.ae/en/

11. Dexter, G. (1999). The Manual of Museum Planning. Rowman \& Littlefield.

12. Dissertation _ Museum. (2014). Retrieved from https://www.slideshare.net/senshots/dissertation-museum

13. Emirate of Abu Dhabi. (n.d.). Retrieved from Wikipedia : https://en Wikipedia. $\mathrm{rg} /$ wiki/ Emirate ofAbu Dhabi

14. Ghazal, R. (June 9, 2014). The man with all our memories.http://www.thenational.ae/uae/heritage/theman-with-all-our-memories.

15. History's First Recorded Museum Was Founded by a Woman. (2011).

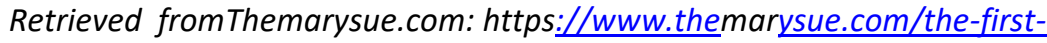
museum/

16. Khaja, D. K. ( 2013). History of Emirati Media. al bayan,http://www.albayan.ae/opinions/articles/2013-0917-1.1961062.

17. Location of the United Arab Emirates [UAE] on the World Map - TEN Guide. (2018). Retrieved fromGuide.theemiratesnetwork: http://quide.theemiratesnetwork.com

18. Louvre Abu Dhabi - Saadiyat Island Abu Dhabi / Saadiyat. . (n.d.). Retrieved from Saadiyat.ae. :http://www.saadiyat.ae/en/inspiration-details/3/LouvreAbu-Dhabi

19. National, T. (October 29, 2013). Abu Dhabi Media signs deal over 


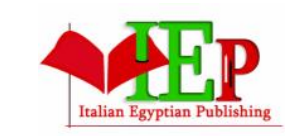

ISSN: $2785-9673$

\section{INTERNATIONAL JOURNAL OF \\ ARCHITECTURAL ENGINEERING AND URBAN \\ RESEARCH}

VOLUME 3 , ISSUE 2, 2020, $1-30$.

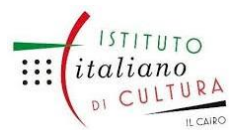

www.egyptfuture.org/ojs/

national archives.http://www.thenational.ae/uae/heritage/abu-dhabi-media-

signs-deal-over-national-archives.

20. Planet, L. (2017). Crossroads of Civilizations Museum in Dubai, United Arab Emirates.

21. Saadiyatbeachclub.ae. (n.d.). Retrieved from

http://www.saadiyatbeachclub.ae/facilities/the-workout-room/

22. The Wilanow Palace Museum. Visit the palace. (n.d.). Retrieved from Wilanow Palace:http://www.wilanow -palac.pl/palace.html

23. Types of museum. (n.d.). Retrieved from Encyclopedia Britannica. : https://www.Britannica.com

24. UNESCO. (November 2013). Table 8: Cinema Infrastructure - Capacity.

25. Wikipedia. (n.d.). Retrieved from En.wikipedia.org. Saadiyat Island: https://en.wikipedia. org/wiki/aadiyat_Island

26. With Disabilities ADA National Network. (n.d.). Retrieved from Adata: https://adata.org/publication/

27. Al-Qasimi, K.M. (1999). Al-Tarikh al-Hadith wa al-Mu'asir li-dawlat al-Imarat, pp. 84-180.

28. Celik, Z. (1992), Displaying the Orient: Architecture of Islam at NineteenthCentury World'sFairs.Berkeley: University of California Press.

29. Dexter, G. (1999), the manual of Museum Planning. Rowman \& little-field publishers.

30. Prosler, M. (1996). "Museums and globalization", Theorizing Museums, Ed. S Macdonald \& J. Fyfe.

31. Macdonald, S, (1996). "Theorizing museums: an introduction", Theorizing Museums, Ed. SMacdonald \& J. Fyfe.

32. Soren, Barbara J.(2009) "Museum experiences that change visitors", Museum Management andCuratorship, 24: 3, $233-251$. 
INTERNATIONAL JOURNAL OF

ARCHITECTURAL ENGINEERING AND URBAN

RESEARCH

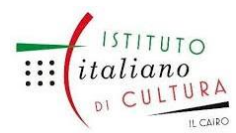

ISSN: 2785-9673

VOLUME 3, ISSUE 2, 2020, 1 - 30 .

www.egyptfuture.org/ojs/

Received: August 00, 2020

Accepted: October 00, 2020 